\title{
Descriptive Investigation of Preschool Education in the Field of The Master's Thesis in Turkey
}

\author{
Gülhan Güven ${ }^{1}$ \\ ${ }^{1}$ Gazi Education Faculty, Gazi Universty, Yenimahalle, Ankara, Turkey \\ Correspondence: Gülhan Güven, Gazi Education Faculty, Gazi Universty, Ankara, Turkey.
}

Received: June 6, 2019

Accepted: July 25, 2019 Online Published: October 12, 2019

doi:10.5539/ies.v12n11p1

URL: https://doi.org/10.5539/ies.v12n11p1

\begin{abstract}
This research was carried to identify characteristics of the master dissertations completed in the field of preschool education, between the years of 2015-2019 in Turkey. The sampling of the study consisted of master dissertations in preschool education, child development and education/home economics department registered to National Dissertations Center database. The design of this study was descriptive study using document analysis model. The main purpose of the study was to bring out arguments that made in the field of preschool education in Turkey. For this purpose 151 master dissertations were analyzed. Results indicated that the majority of the master level dissertations related to preschool education were completed in 2015. Most of these researches were studied in Gazi University and quantitative statistic methods were preferred. The common subject was personal competence.
\end{abstract}

Keywords: early childhood, master thesis, preschool

\section{Introduction}

Childhood years are a critical period and form the basis of human life. The ability of individuals to become productive individuals in society by effectively using their abilities for healthy personality development depends on the experiences gained in childhood. The child gains these experiences by communicating with the environment, exploring the environment through active experiments and benefiting from various educational environments (Aral, Fındık-Tanrıbuyurdu, Yurteri-Tiryaki, Sağlam, \& Aysu, 2015).

When the developments in early childhood education in Turkey are examined, it is seen that first attempts started with the Ottoman Empire. During the Ottoman Empire's constitutional monarchy period, there were several attempts made for young children's education. The first kindergarten schools were established for Turkish children in this period. In 1914, the Modern Turkish Republic Ministry of Education allocated money for early childhood education for the first time and planned to build ten preschools in Istanbul (Ahi \& Kildan, 2013). During modern Republic period, the Fourth National Education Council focused on family education in 1949. After that the Fifth National Education Council decided opening preschool institutions. Besides, the aim and duties of these institutions were updated. However, the major change in preschool education was started in 2005 (Güven \& Azkeskin, 2010). Countrywide governmental and nongovernmental investments were made, a new education program was implemented based on constructivist approach and public awareness towards preschool education was increased.

When we examine the teacher education programs for children, systematic steps were taken during republic period. During this period, Vocational Child Development and Education department was instituted in Girls' Vocational High Schools in 1963 and 1964. The Council of Higher Education was established in 1981 and teacher education programs were assigned to this organization. Four years of undergraduate level child development programs were started to open in vocational education faculties and health sciences faculties after this assignment. Following child development departments, undergraduate level early childhood education programs were established in educational faculties as well. For the last ten years, pre-school teaching undergraduate programs have become one of the important programs of education faculties (Dağlığlu, 2012).

Postgraduate studies in preschool education in Turkey have been increased in accordance with the new undergraduate programs. First graduate studies aimed to develop capacity of conducting extensive research and develop the quality of related literature (Bakioglu \& Gurdal, 2001). This also brought a certification process that 
improves the certain rules and scientific instructions to be able to complete a dissertation. This process was necessary to reveal what is done and what should be done, to determine the variables related to the subject, to gain perspective about the field, to form the content of the subject, to reveal the research methods and techniques used in theses (Hart, 2000).

\subsection{Purpose of the Research}

The purpose of this research was to identify characteristics of the master dissertations completed in the field of preschool education, between the years of 2015-2019 in Turkey. For this purpose, the following questions were sought.

1) What is the distribution of master dissertations completed in the field of preschool education in Turkey according to the years?

2) What subjects were chosen for the master dissertations in the field of preschool education in Turkey?

3) What research methods were applied for the master dissertations in the field of preschool education in Turkey?

4) What is the distribution of master dissertations completed in the field of preschool education in Turkey according to the intuitions?

\subsection{Limitations of the Research}

This study was limited by the master dissertations in preschool education, child development and education/home economics department registered to National Dissertations Center database.

\section{Methods and Research Model}

This study is a qualitative descriptive research using descriptive document analysis model. Document analysis involves the analysis of written materials containing information about the cases or cases that are targeted for investigation (Yıldırım \& Şimşek, 2006). The descriptive document analysis in an approach was based on the analysis of those with internet connection or concept (Rapley, 2007). Documents are collected for a purpose. Collected words are analyzed and interpreted (Bowen, 2009). In this study, four main stages were followed in document review.

1) Access to documents,

2) Understanding the documents,

3) Analyzing the data,

4) Interpretation of data.

\subsection{Universe and Sample}

The universe of the study constitutes the thesis work in the field of early childhood education made in Turkey between the years January 2015-July 2019 according to National Thesis Center. The sample of the study was determined with criterion sampling method. The criterion in this research was, theses were conducted between 2015 and 2019 and they were registered to the National Thesis Center in the Department of Preschool Education and Child Development and Education/Home Economics. Within the scope of the research, 151 Master's theses prepared in the Department of Preschool Education and Child Development and Education/Home Economics were examined.

\subsection{Data Collection}

In the first stage of the study, the thesis was scanned with the keywords "pre-school and pre-school education by screening option in the National Thesis Center. It was limited to master's degree and the years of 2015-2019. Total of 151 theses were reached. The data for 2019 cover the 7-month period until the end of July. Therefore, the number of theses for 2019 is less than previous years.

\subsection{Data Analysis}

The data collected in this study were conceptualized. Themes explaining the data were determined according to concepts. Significant parts of the data that were subjected to content analysis were named and classified under certain themes. The data was classified by using the SPSS for Windows version 24.0 package program with the frequency and percentage values of descriptive statistics tools. The results were presented in tables.

\section{Finding}

The findings of the study were analyzed on the bases of the research questions. 
Table 1 shows the distribution of master's theses in the field of preschool education between the years 2015-2019.

Table 1. Master theses in preschool education frequency and percentage table of distribution by years

\begin{tabular}{ccc}
\hline Year & $\mathrm{f}$ & $\%$ \\
\hline 2015 & 58 & 38.4 \\
2016 & 39 & 25.8 \\
2017 & 15 & 9.9 \\
2018 & 27 & 17.9 \\
2019 & 12 & 7.9 \\
\hline Total & 151 & 100 \\
\hline
\end{tabular}

When the Table 1 is examined, it is determined that a total of 151 master's theses have been prepared for pre-school education between 2015 and 2019. In 2015, 58 theses on pre-school education were published and the highest number of studies was realized with a percentage of $38.3 \%, 39$ theses $(25.8)$ in 2016,15 theses $(9.9 \%)$ in 2017, 27 theses (17.9\%) in 2018 and 12 theses (7.9\%) in seven months of 2019 were published. In the study, the thesis made between the years 2015-2019 in Turkey showed that most studied were carried out between 2015-2016 years.

Table 2. Frequency and percentage table of distribution of master theses in preschool education by university

\begin{tabular}{lcc}
\hline University & $\mathrm{f}$ & $\%$ \\
\hline Gazi University & 23 & 15.2 \\
Ankara University & 6 & 4.0 \\
Hacettepe University & 6 & 4.0 \\
ODTÜ University & 6 & 4.0 \\
Marmara University & 11 & 7.3 \\
Okan University & 7 & 4.6 \\
Necmettin Erbakan University & 9 & 6.0 \\
Selçuk University & 13 & 8.6 \\
Çukurova University & 5 & 3.3 \\
Bahçeşehir University & 3 & 2.0 \\
Adnan Menderes University & 5 & 3.3 \\
Dokuz Eylül University & 5 & 3.3 \\
Pamukkale University & 4 & 2.6 \\
Dumlupınar University & 8 & 5.3 \\
Çanakkale University & 13 & 8.6 \\
Abant İzzet Baysal University & 4 & 2.6 \\
Ege University & 2 & 1.3 \\
Karabük University & 1 & 0.7 \\
İstanbul University & 4 & 2.6 \\
Mehmet Akif Ersoy University & 4 & 2.6 \\
Trakya University & 3 & 2.0 \\
Yıldız Teknik & 1 & 0.7 \\
Kastamonu University & 3 & 2.0 \\
Anadolu University & 3 & 2.0 \\
Yıldırım Beyazıt University & 1 & 0.7 \\
İnönü University & 1 & 0.7 \\
\hline Total & 151 & 100 \\
\hline & &
\end{tabular}

When Table 2 is examined, it is seen that the master's theses made in the field of preschool education are mostly done in Gazi University (15.2\%). Selcuk, Çanakkale (8.6\%), Marmara (7.3\%), Necmettin Erbakan (6.0\%), Dumlupınar (5.3\%), Okan (4.6\%), Ankara, Hacettepe and METU (4.0\%), respectively. Çukurova, Adnan Menderes, Bahçeşehir and Dokuz Eylül (3.3\%), Pamukkale, Abant İzzet Baysal, İstanbul and Mehmet Akif 
Ersoy (2.6\%) followed them and then, Thrace, Kastamonu and Anatolia (2.0), Aegean (1.3\%). It was found that the thesis study was conducted the least in Karabük, Yıldırım Beyazıt and İnönü (0.7\%) Universities.

The reason for the high number of theses of Gazi University is that the number of its academic staff is higher than other universities. In addition, the fact that Gazi University has an important role in teacher training can be considered as another reason. Dilek, Beysan, and Ozturk (2018) showed in their study in Turkey that the general trend of higher licensing criteria in the area of Social Sciences, when the number of master's theses are taken in to consider Gazi University. Can-Yasar and Aral (2001) examined the thesis made in the field of drama in preschool education as aresult, they determined that Ankara University and Gazi University took the first two pieces.

Table 3. Frequency and percentage table of distribution of master theses in the field of preschool education

\begin{tabular}{lcc}
\hline Department & f & $\%$ \\
\hline Early Childhood Education & 125 & 82.8 \\
Child Development and Education/Domestic Economy & 26 & 17.2 \\
\hline Total & 151 & 100 \\
\hline
\end{tabular}

As can be seen in Table 3, it was found that $82.8 \%$ of the master theses conducted between 20152019 were the Department of Preschool Education. Master's thesis in the field of child development and education/home economics is $17.2 \%$. Preschool Education/Science is included in the Faculty of Education, Pre-School Education is spreading and gradually increasing the importance of Preschool Education, Child Development and Education is thought to be caused by the restructuring of YÖK and closure of Faculties of Vocational Education.

Table 4. Master theses in the field of preschool education frequency and percentage table of distributions by working group

\begin{tabular}{lcc}
\hline Participants & $\mathrm{f}$ & $\%$ \\
\hline Teacher & 34 & 22.5 \\
Children & 54 & 35.8 \\
Parents & 8 & 5.3 \\
Prospective Teacher & 7 & 4.6 \\
Others & 48 & 31.8 \\
\hline Total & 151 & 100 \\
\hline
\end{tabular}

When Table 4 is examined, the subjects of the master's theses published in the field of preschool education are mostly children (35.8\%). The other group consists of $31.8 \%$ (teacher-child, teacher-child-mother, teacher-staff, teacher-manager, teacher-teacher candidate) as the study group consists of more than one study group in children. These were followed by teachers $(22.5 \%)$, parents $(5.3 \%)$, and prospective teachers $(4.6 \%)$. In the thesis, children come first. It is expected that children, who are the most important stakeholders directly involved in the field, will take the first place as a working group. Similarly, Ahi and Kildan (2013) showed that children took the first place as the study group in their master thesis in the field of preschool education.

Table 5. Frequency and percentage table of the distributions of the methods used in master's theses in the field of preschool education

\begin{tabular}{lll}
\hline Method & $\mathrm{f}$ & $\%$ \\
\hline Quantitative & 101 & 66.9 \\
Qualitative & 38 & 25.2 \\
Mixed & 12 & 7.9 \\
\hline Total & 151 & 100 \\
\hline
\end{tabular}

According to Table 5, one can see that the most preferred quantitative study $(66.9 \%)$ was used in the master's theses in the field of pre-school education, the qualitative study was ranked second (25.2\%) and the least mixed method (7.9\%) was used. Many studies to examine postgraduate thesis in Turkey, similar results were obtained 
regarding the methodology of the study. The fact that more quantitative research method is preferred in researches, data collection and data analysis is easier, and it does not require more time and effort can be thought to result from the fact that researchers have sufficient knowledge and skills about the quantitative research method. Baba et al. (2011) stated that quantitative research is due to the fact that it can be performed in a shorter time when compared to other methods, while Yildız (2004) suggests that qualitative studies may be low due to the insufficient courses of scientific research methods in universities.

Table 6. Frequency and percentage table of distributions according to the study designs of the master's theses made in the field of preschool education

\begin{tabular}{lcc}
\hline Research Design & $\mathrm{f}$ & $\%$ \\
\hline Descriptive/Scanning & 58 & 38.4 \\
Experimental & 18 & 12.0 \\
Explanatory & 1 & 0.6 \\
Comparative & 4 & 2.6 \\
Phenomenol & 4 & 2.6 \\
Case Study & 5 & 3.3 \\
Exploratory & 2 & 1.3 \\
Correlational Scanning & 38 & 25.1 \\
Document Analysis & 4 & 2.6 \\
Fact-Based & 4 & 2.6 \\
Others & 13 & 8.7 \\
\hline Total & 151 & 100 \\
\hline
\end{tabular}

According to Table 6, descriptive/screening was the most preferred research design. After descriptive/screening, relational screening (25.1\%), experimental (12.0\%), case study (3.3\%), comparison, phenomenology, document analysis and due diligence (2.6\%) were preferred as the research design. In the dissertations, exploratory and exploratory patterns were the least preferred. Other category; 6 of the master theses included in the research did not specify patterns and 7 of them could not be determined due to the limitation of use. In the research, the desirable/descriptive/screening method, which is one of the most preferred design methods in master's theses between 2015 and 2019, is aimed to reveal the status of the participants. Ozan and Köse (2014) emphasized that the majority of the researchers preferred descriptive scanning patterns in the articles in their study in which they examined research trends in educational programs and teaching. Again, Dilek et al. (2018) found that the most preferred screening was descriptive scanning patterns in their research. Kozikoğlu and Semenoğlu (2015) showed the same result as in their studies. According to the results obtained from the research, the reason for preferring screening/descriptive design is reaching more people in a shorter time; data collection and analysis.

Table 7. Master theses in the field of preschool education frequency and percentage table of distribution by subjects

\begin{tabular}{lcc}
\hline Study Subjects & $\mathrm{f}$ & $\%$ \\
\hline Technology & 10 & 6.6 \\
Health & 1 & 0.7 \\
Institution & 1 & 0.7 \\
Educational Approaches & 27 & 17.9 \\
Program & 21 & 13.9 \\
Vocational Competence & 26 & 17.2 \\
Assessment & 9 & 6.0 \\
Development Areas & 24 & 15.9 \\
Individual Competence & 30 & 19.9 \\
Value Education & 2 & 1.3 \\
\hline Total & 151 & 100 \\
\hline
\end{tabular}

When Table 7 is examined, $19.9 \%$ of the subjects preferred in the studies were conducted in the field of personal competence (achievement, behavior, relationship, skill). Other subjects are respectively learning and teaching 
approaches $17.9 \%$, professional competence $17.2 \%$, development areas $15.9 \%$, program $13.9 \%$, technology $6.6 \%$, evaluation $6.0 \%$, and values education $1.3 \%$. The least studied subject is health and institution.

The reason why researchers prefer these topics most is that there are many data collection tools in this area, they are easier to access and they face fewer problems in terms of applicability. B1kmaz et al. (2013) found that the variables that affect academic achievement, attitude, and skill of the researchers are preferred by the researchers as the subject in their study which examined their $\mathrm{PhD}$ thesis.

\section{Result and Suggestions}

\subsection{Result}

In this study, thesis made in Turkey between the years of 2015-2019, the years, universities, majors, the sciences, the study group, method, according to the study aimed to investigate the pattern and subject matter. The results obtained according to the findings obtained for this purpose and the recommendations regarding the results can be listed as follows.

In this research, 151 master's theses were reached. In the research, it was determined that the master theses about preschool education were mostly studied between 2015 and 2016. With $38.4 \%$, 2015 was the year with the highest number of studies.

In the distribution of master's theses in the field of preschool education according to universities, Gazi University (15.2\%) conducted the most studies among the years examined. It was concluded that the master's theses in the field of preschool education were mostly conducted in the Department of Preschool Education/Science (82.8\%) between 2015 and 2019.

In the research, it was found out that children were preferred most as the study group of master's theses.

In the research, it was found that quantitative method was used more, qualitative research methods were preferred in the second place and mixed methods were used the least in the theses published between 2015 and 2019.

In the research, the most preferred design between 2015 and 2019 is descriptive/screening which is one of the quantitative research methods and generally aims to reveal the situations of the participants. The descriptive/screening pattern was followed by relational screening (25.1\%) and experimental (12.0\%). Among the research designs, the least exploratory sequential design was preferred.

When the master's theses made in the field of preschool education between 2015-2019 were examined, it was determined that personal competence, teaching and learning approaches, occupational competence, development areas and program subjects were mostly studied respectively.

\subsection{Suggestions}

According to the results of the research, it is revealed that the majority of the studies prefer to use the quantitative research method. Although quantitative research provides convenience in terms of applicability, it is limited in terms of identifying problems and producing solutions. For this reason, it is thought that giving more weight to quantitative and mixed methods will contribute to the field in order to make more in-depth investigations and obtain reliable results.

\section{References}

Ahi, B., \& Kıldan, A. O. (2013). Türkiye'de Okul Öncesi Eğitimi Alanında Yapılan Lisansüstü Tezlerin İncelenmesi (2002-2011). Mehmet Akif Ersoy Üniversitesi Ĕgitim Fakültesi Dergisi, 13(27), 23-46.

Altun, D., Şendil, Ç. Ö., \& Şahin İ. T. (2011). Investigating the national dissertation and thesis database in the field of early childhood education in Turkey. Procedia Social and Behavioral Sciences, 12, 483-492. https://doi.org/10.1016/j.sbspro.2011.02.060

Aral, N., Fındık-Buyurdu, E., Yurteri-Tiryaki, A., Sağlam, M., \& Aysu, B. (2015). Investigation of graduate theses in the field of child development in Turkey. Ankara Health Services Journal, 14(1), 7-16.

Bakioglu, A., \& Gürdal, A. (2001). Lisansüstü tezlerde danışman ve öğrencilerin rol algıları: yönetim için göstergeler. Hacettepe Üniversitesi Ĕ̈itim Fakültesi Dergisi, 21(1), 9-18.

Bertan, M., Haznedaroğlu, D., Koln, P., Yurdakök, K., \& Güçiz, B., D. (2009). Ülkemizde erken çocukluk gelişimine ilişkin yapılan çalışmaların derlenmesi (2000-2007). Çocuk Sağglı̆̆l ve Hastalıkları Dergisi, 52, $1-8$.

Bikmaz, F. H., Aksoy, E., Tatar, O., \& Altinyuzuk, C. A. (2013). The content analysis of PhD theses completed in 
the field of curriculum and instruction (1974-2009). Egttım Ve Bllım-Educatıon and Sclence, 38(168), 288-303.

Bowen, G. A. (2009). Document analysis as a qualitative research method. Qualitative Research Journal, 9(2), 27-40. https://doi.org/10.3316/QRJ0902027

Can-Yaşar, M., \& Aral, N. (2011). Türkiye'de okul öncesinde drama alanında yapılan lisansüstü tezlerin incelenmesi. Mehmet Akif Ersoy Üniversitesi Ĕ̆itim Fakültesi Dergisi, 11(22), 70-90.

Dağlığlu, H. E. (2012). Okul öncesi öğretmeninin özellikleri ve okul öncesi eğitime öğretmen yetiştirme. In G. Haktanır (Ed.), Okul Öncesi Eğitime Giriş (pp. 39-80).

Dilek, A., Baysan, S., \& Öztürk, A. A. (2018). Türkiye’De Sosyal Bilgiler Eğitimi Üzerine Yapilan Yüksek Lisans Tezleri: Bir İçerik Analizi Çalişmasi. Turkish Journal of Social Research/Turkiye Sosyal Arastirmalar Dergisi, 22(2), 581-602.

Güven, G., \& Azkeskin, K. E. (2010). Erken çocukluk eğitimi ve okul öncesi eğitim. In İ. H. Diken (Ed.), Erken çocukluk eğitimi. Ankara: Pegem A.

Hart, C. (2000). Doing a literature review. Releasing the social science research imagination. London: SAGE Publications.

Kozikoğlu, İ., \& Senemoğlu, N. (2015). Content Analysis of Structures Ph.D. in Curriculum and Teaching Areas (2009-2014). Education and Science, 182, 29-41.

Ozan, C., \& Köse, E. (2014). Research trends in educational programs and teaching. Sakarya University Journal of Education, 4(1), 116-136. https://doi.org/10.19126/suje.76547

Rapley, T. (2007). Doing conversation, discourse and document analysis. London: SAGE. https://doi.org/10.4135/9781849208901

Yıldırım, A., \& Şimşek, H. (2006). Sosyal bilimlerde nitel araştırma yöntemleri (Genişletilmiş 6. Baskı). Ankara: Seçkin Yayıncılık.

Yıldız, A. (2004). Türkiye'deki yetişkin eğitimi araştırmalarına toplu bakış. Ankara Üniversitesi Eğitim Bilimleri Fakültesi Dergisi, 37(1), 78-97.

\section{Copyrights}

Copyright for this article is retained by the author(s), with first publication rights granted to the journal.

This is an open-access article distributed under the terms and conditions of the Creative Commons Attribution license (http://creativecommons.org/licenses/by/4.0/). 